\title{
Is cAMP decrease essential for resumption of meiosis in mouse oocytes?
}

\author{
E Nagyová 1, J Kalous 2*, P Š utovský 2, J Motlík 2 \\ ${ }^{1}$ Research Institute of Animal Production, 104-00 Prague 10, Uhrineves; \\ 2 Institute of Physiology and Genetics of Animals, Czech Academy of Science, \\ 27721 Libéchov, Czech Republic
}

(5th Franco-Czechoslovak Meeting, Jouy-en-Josas, December 1992)

\begin{abstract}
Summary - Resumption of meiosis was inhibited in mouse oocyte cumulus complexes (OCC) cocultured with pig membrana granulosa (PMG). After 3 and $6 \mathrm{~h}$ of co-culture these oocytes possessed an intact nuclear envelope and their nucleolar surface was associated with granules $\approx 80 \mathrm{~nm}$ in diameter. Preincubation of OCCs for $30,45,60$ or 90 min followed by co-culture with PMG for $2 \mathrm{~h}$ of either OCCs or denuded oocytes resulted in germinal vesicle breakdown (GVBD) in $\approx 0,30,70$ and $100 \%$ mouse OCCs and in $\approx 30,60,80$ and $100 \%$ denuded oocytes, respectively. It seems that the inhibitory contact between mouse oocytes and PMG was established during the first $h$ of coculture. After isolation from antral follicles the oocytes contained $2.75 \mathrm{fmol}$ cyclic adenosine $3^{\prime}, 5^{\prime}$ monophosphate (CAMP). When OCCs were co-cultured for 1,2 or $3 \mathrm{~h}$ with $\mathrm{PMG}$, the amount of CAMP per oocyte was $1.34,1.33$ and $1.51 \mathrm{fmol}$, respectively. After culture of OCCs in control medium the amount of CAMP was $1.21,1.39$ and $2.16 \mathrm{fmol}$, respectively. The present results suggest that the inhibitory activity of PMG is not species-specific. Moreover, PMG prevented resumption of meiosis in mouse oocytes in spite of the cAMP drop in oocyte cytoplasm characteristic of the resumption of meiosis.
\end{abstract}

\section{mouse oocyte / meiosis / CAMP / pig membrane granulosa}

Résumé - La décroissance de l'AMPc est-elle essentielle pour la reprise de la mélose dans les ovocytes de souris ? La reprise de la méiose a été inhibée dans des complexes ovocytecumulus (OCC) de souris cocultivés avec de la "membrana granulosa" de porc (PMG). Ces ovocytes conservent une enveloppe nucléaire après 3 et $6 \mathrm{~h}$ de coculture et la surface nucléolaire est associée avec des granules de $80 \mathrm{~nm}$ de diamètre. La préincubation des OCCs pendant $30,40,60$ ou 90 min puis la coculture avec la PMG d'OCCs ou d'ovocytes dénudés aboutit à la rupture de la vésicule germinative (GVBD) dans environ 0, 30, 70 et 100\% des OCCs et environ 30,60, 80 et $100 \%$ des ovocytes dénudés, respectivement. II semble que linhibition par contact entre la PMG et les ovocytes s'établisse pendant la première heure de coculture. Après isolement de follicules à l'antrum, les ovocytes contiennent 2,75 fmol d'adénosyl 3'5' monophosphate cyclique (AMPc). Quand les OCCs sont cocultivés pendant 1,2 ou $3 \mathrm{~h}$ avec la PMG, la concentration d'AMPc par ovocyte est respectivement de 1,34; 1,33 et 1,51 fmol. Après culture des OCCs dans le milieu témoin, la concentration d'AMPC est alors de 1,21; 1,39 et 2,16 fmol. Les résultats présents suggèrent que l'activité inhibitrice de la PMG n'est pas limitée à l'espèce. De plus, la PMG empêche la reprise de la méiose d'ovocytes de souris en dépit de la chute d'AMPC, caractéristique de cette reprise, dans le cytoplasme ovocytaire.

* Correspondence and reprints 


\section{INTRODUCTION}

The hypothesis that the antral follicles inhibit the resumption of meiosis until the preovulatory gonadotropin surge was first put forward by Pincus and Enzman (1935). Further studies have confirmed that either intrafollicularly or under in vitro conditions, the membrana granulosa and cumulus granulosa cells are required for the prevention of oocyte maturation (Foote and Thibault, 1969; Tsafriri and Channing, 1975; Leibfried and First, 1980; Racowsky and Baldwin, 1989). In addition, pig oocytes surrounded by the cumulus with a part of membrana granulosa directly adjacent to the cumulus do not mature in gonadotropin-free medium (Mattioli et al, 1988; Motlik et al, 1991). We have recently found that under suitable culture conditions a piece of pig membrane granulosa (PMG) is able to prevent resumption of meiosis in cattle oocytes (Kalous et al, 1993). This heterologous effect of PMG was used in the present experiments when the mouse OCCs (OCC) were co-cultured with a piece of $P M G$.

Under in vitro conditions, analogs of cAMP and phosphodiesterase inhibitors prevent spontaneous meiotic resumption in mouse (Cho et al, 1974; Wassarman et al, 1976) and rat oocytes (Magnusson and Hillensjo, 1977; Dekel and Beers, 1978). These findings imply that a drop in the cAMP levels in rodent oocytes is related to germinal vesicle breakdown (GVBD). In fact, a decrease in oocyte cAMP precedes GVBD in mouse (Schultz et al, 1983a, b; Vivarelli et al, 1983) and rat oocytes (Racowsky, 1984; Aberdam et al, 1987).

The present experiments were undertaken to answer 2 questions: first, does PMG prevent resumption of meiosis in oocytes with a rapid time sequence of GVBD? Second, does co-culture with PMG influence cAMP levels in the cytoplasm of the mouse oocytes?

\section{MATERIALS AND METHODS}

\section{Oocytes and granulosa cells}

Mouse oocytes were isolated from large antral follicles of sexually mature females (strain A) primed $48 \mathrm{~h}$ before with $5 \mathrm{IU}$ pregnant mare serum gonadotropin. Only oocytes surrounded by compact cumulus were chosen for these experiments. Membrana granulosa was isolated from ovaries of slaughtered prepubertal gilts. Only large antral follicles $(7-10 \mathrm{~mm}$ in diameter) with a transparent, vascularized follicular wall were dissected. With the help of 2 preparation needles, large pieces of granulosa layer were carefully separated from the theca. Only pieces of the PMG containing $\approx 1-3 \times 10^{5}$ granulosa cells were used. A previous ultrastructural study (Kalous et al, 1993) revealed that PMG was always isolated with the basement membrane.

\section{Co-culture of mouse oocytes with pig membrana granulosa}

In the present experiments modified Parker's culture medium (M-199, Sevac, Prague) supplemented with $2.92 \mathrm{mM}$ Ca-lactate, $2 \mathrm{mM} \mathrm{Na}-$ pyruvate, $33.9 \mathrm{mM} \mathrm{Na-bicarbonate,} 4.43 \mathrm{mM}$ Hepes buffer, $50 \mathrm{IU} / \mathrm{ml}$ penicillin, $50 \mathrm{mg} / \mathrm{ml}$ streptomycin sulfate, and $10 \%$ heat-treated bovine serum (BOS, Sevac, Prague) was used (Pavlok et al, 1988).

About 15 mouse OCCs were placed on the basement membrane (concave side) of each piece of $P M G$ and cultured in $0.5 \mathrm{ml}$ Parker's medium under paraffin oil at $38^{\circ} \mathrm{C}$ under $5 \%$ $\mathrm{CO}_{2}$ in air for $1,2,3$, or $6 \mathrm{~h}$. In preincubation experiments, $\approx 10$ OCCs were cultured in $0.1 \mathrm{ml}$ of the medium under the above-described conditions for $30,45,60$ and 90 min before either oocytes with compact cumulus or oocytes with mechanically removed cumulus (cumulus-free oocytes) were co-cultured for $2 \mathrm{~h}$ with PMG.

As a control, mouse OCCs were cultured in the control medium (control I) or in the medium with several pieces of PMG but without direct contact with them (control II). In further control experiments, the PMG basement membrane was covered with a nitrocellulose membrane. Both the adhered membranes and OCCs were 
situated on the nitrocellulose membrane and were cultured for $3 \mathrm{~h}$.

At the end of the culture period, OCCs were removed from contact with $P M G$ and used either for light and electron microscopic evaluation or for cAMP determination.

\section{Determination of CAMP by radioimmunoassay (RIA)}

After isolation $(0 \mathrm{~h})$ or incubation $(1,2$ or $3 \mathrm{~h})$ the OCCs were transferred to medium containing $1 \mathrm{mM}$ 3-isobutyl-1-methylxanthine (IBMX) to minimize cAMP hydrolysis within the cells. Cumulus cells were mechanically removed from the oocytes. Denuded oocytes were washed 3 times in the medium with IBMX and then transferred into $10 \mu \mathrm{l} 0.5 \%$ sodium dodecyl sulfate (SDS, w/v; Racowsky, 1984). When lysis was completed, the samples were capped and stored at $-80^{\circ} \mathrm{C}$. Before extraction with $100 \mu \mathrm{l}$ $6 \%$ trichloroacetic acid (TCA) at $4{ }^{\circ} \mathrm{C}, 10 \mu \mathrm{l}$ bovine serum albumin $(10 \mathrm{mg} / \mathrm{ml})$ was added to each microcap to act as carrier protein. The extracted samples were centrifuged at $2000 \mathrm{~g}$ for $15 \mathrm{~min}$ and supernatants were removed and lyophilized. TCA extracts were diluted and assayed after acetylation. Cyclic AMP was measured by radioimmunoassay using kits (UVVVR, Prague) (Procházka et al, 1991). The sensitivity of the assay was $4 \mathrm{fmol} /$ tube. The intra- and interassay coefficients of variation in this RIA were 7.8 and $10.2 \%$. The significance of the differences in cAMP concentrations between experimental groups was assessed using the Student's $t$ test.

\section{Light microscopy}

To prepare the OCCs for light microscopy cumulus cells were mechanically removed. Oocytes were mounted on slides, fixed in an acetic acid/ alcohol (1:3) mixture for $24 \mathrm{~h}$, stained with orcein and examined under a phase-contrast microscope. Frequency of GVBD in I and II was calculated from data pooled from 3 replicate experiments and the frequency of GVBD between groups was compared by $\chi^{2}$ analysis.

\section{Electron microscopy}

Samples were fixed in a mixture of $0.6 \%$ paraformaldehyde and $2.5 \%$ glutaraldehyde in 0.2 cacodylate buffer $(\mathrm{pH} \mathrm{7.4)}$ for 90 min, washed, postfixed in $1 \% \mathrm{OsO}_{4}$ in cacodylate buffer for 1 $\mathrm{h}$ and dehydrated in ascending ethanol series. After infiltration in a mixture composed of propylene oxide and Epon, the samples were embedded in Epon 812. The blocks were cut in Reichert-Jung Ultracut, mounted on grids, contrasted with uranyl acetate and lead citrate, and examined in a Jeol 1200 EX electron microscope.

\section{RESULTS}

\section{Co-culture}

When the freshly isolated mouse OCCs were cultured on PMG, the OCCs did not resume meiosis during the 3-h (table $\mathrm{I}$ ) and 6-h (data not shown) co-culture period. The mouse denuded oocytes were also blocked at the GV stage by PMG. In contrast, mouse OCCs cultured in the same drop of medium but without direct contact with PMG matured spontaneously. A sheet of nitrocellulose membrane between PMG and OCCs abolished the inhibitory effect of PMG upon mouse oocytes. It was concluded that the direct contact of the mouse denuded or cumulus-enclosed oocytes with PMG was essential to prevent resumption of meiosis.

Fifty-six percent of the mouse oocytes denuded after the 45-min preincubation period underwent GVBD during the subsequent 2-h co-culture with PMG (table II). The cumulus-enclosed oocytes required 60-min preincubation to undergo GVBD $(66 \%)$ during the co-culture period. These data indicate that the inhibitory effect of PMG upon GVBD was effective in the commitment period only. 
Table I. GVBD in mouse OCCs co-cultured with PMG and nitrocellulose membrane.

\begin{tabular}{lcccc}
\hline Type of culture & No of oocytes & \multicolumn{2}{c}{ Stage of meiosis } & GVBD (\%) \\
\hline Control I & 54 & 2 & 53 & $96^{\mathrm{a}}$ \\
Control II & 59 & 3 & 47 & $95^{\mathrm{a}}$ \\
OCCs and PMG & 46 & 46 & - & $0^{\mathrm{b}}$ \\
OCCs and NM & 51 & 1 & 50 & $98^{\mathrm{a}}$ \\
OCCs and PMG + NM & 47 & 2 & 45 & $96^{\mathrm{a}}$ \\
\hline
\end{tabular}

Mouse OCCs were cultured for $3 \mathrm{~h}$ in control medium (control I), in the presence of PMG without contact with PMG (control II), in contact with PMG (OCCs and PMG), in contact with nitrocellulose membrane (OCCs and NM) and in contact with nitrocellulose membrane adhering to PMG (OCCs and PMG + NM). Values with different superscripts are significantly different $(P<0.05)$.

\section{cAMP levels}

In the control medium, all oocytes underwent GVBD during $3 \mathrm{~h}$ of culture. The alterations in intraoocyte cAMP content in oocytes during culture are shown in table III and figure 1. The oocyte intracellular cAMP content was $2.75 \pm 0.24 \mathrm{fmol} /$ oocyte before incubation $(0 \mathrm{~h})$. The significant drop in intraoocyte cAMP content, which was detected after $1 \mathrm{~h}$ of incubation (1.21 $\pm 0.07 \mathrm{fmol} /$ oocyte), was followed by GVBD. After co-culture with PMG, the resumption of meiosis was prevented during 1,2 or $3 \mathrm{~h}$ of incubation, but surprisingly the significant cAMP drop was detected in the mouse oocytes ( $1.34 \pm 0.12 \mathrm{fmol} /$ oocyte) after $1 \mathrm{~h}$ of co-culture. No significant difference was observed in the intraoocyte cAMP content after $1 \mathrm{~h}$ incubation when the control and $P M G$ groups were compared.

Table II. The effect of PMG upon GVBD in preincubated mouse OCCs.

Cumulus-enclosed oocytes

$\begin{array}{lcccccccccc}\operatorname{Min} & 0 & 30 & 45 & 60 & 90 & 0 & 30 & 45 & 60 & 90 \\ \text { GVBD (\%) } & 0^{\mathrm{a}} & 0^{\mathrm{a}} & 31^{\mathrm{b}} & 66^{\mathrm{c}} & 100^{\mathrm{d}} & 0^{\mathrm{a}} & 34^{\mathrm{b}} & 56^{\mathrm{c}} & 77^{\mathrm{d}} & 100^{\mathrm{e}}\end{array}$

Mouse OCCs were preincubated for $30,45,60$ and 90 minutes in control medium and subsequently OCCs (cumulus-enclosed oocytes) and oocytes after mechanical removing of cumulus (cumulus-free oocytes) were co-cultured with PMG for $2 \mathrm{~h}$. Each interval was repeated 3 times and at least 50 oocytes were used. Values with different superscripts are significantly different $(P<0.05)$ 
Table III. Cyclic AMP levels in oocytes incubated without PMG.

\section{Group}

C- $\quad$ OCC

$\begin{array}{lllll}\text { Time }(\mathrm{h}) & 0 & 1 & 2 & 3 \\ \text { Mean } & 2.75^{\star} & 1.21 & 1.39 & 2.16 \\ \text { SEM } & 0.24 & 0.07 & 0.24 & 0.23\end{array}$

The mouse oocyte cumulus complexes (OCC) were cultured for 1,2 , and $3 \mathrm{~h}$ in control medium. The oocytes were denuded ( $\mathrm{C}-$ ) before (time zero) or after incubation in control medium (time 1, 2 and $3 \mathrm{~h}$ ). Values represent the mean fmol CAMP per oocyte and the SEM from at least 3 independent experiments. ${ }^{*}$ The time zero is significantly different from that of other groups $(P<0.05)$.

\section{Electron microscopy}

The co-culture of mouse OCCs with PMG resulted in the close attachment of mouse cumulus cells (CC) to the pig basement membrane (BM) (fig 2). The cells in the mouse cumulus were interconnected by extensive network of gap junctions (GJs) at all time points $(0,3,6 \mathrm{~h}$ of culture) (fig 3A). Similarly, a large number of GJs coupled PMG cells during co-culture (fig $3 B$ ). Finally, the cytoplasmic projections of mouse corona radiata cells remained in contact with the oocyte after $6 \mathrm{~h}$ co-culture with PMG (fig 4). The direct contact between cytoplasmic membranes of PMG cells and mouse $C C$ was prevented by the presence of the continuous pig BM (fig 5). In no case did the cells from the pig or mouse compartment of the co-culture system penetrate across the BM. In areas where the space between mouse cumulus and pig MG was enlarged, the BM was differentiated into 2 distinguishable layers (lamina rara densa and lamina lucida) (fig 5).

The nuclear ultrastructure of mouse oocytes underwent substantial changes after co-culture with PMG (fig 6). Whereas the nuclear envelope remained intact, the compact nucleoli were surrounded by a conspicuous rim composed of nucleolusassociated chromatin and large granules $\approx 80 \mathrm{~nm}$ in diameter. The same granules formed small clusters in the nucleoplasm.

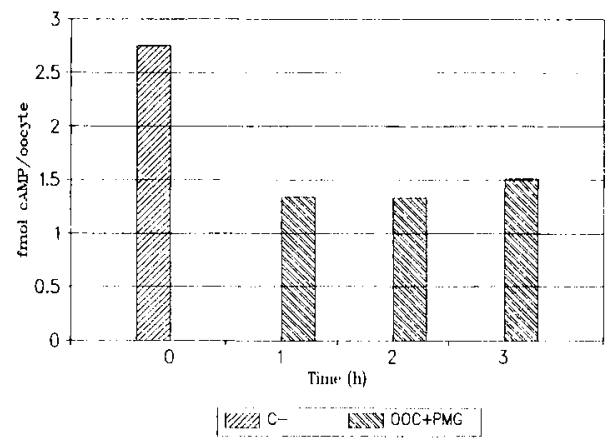

Fig 1. Effect of pig membrana granulosa on the content of cAMP in mouse oocytes. The mouse oocyte cumulus complexes (OCC) were cultured for 1,2 and $3 \mathrm{~h}$ upon pig membrana granulosa (OCC + PMG). The oocytes were denuded of cumulus cells (C-) before (time zero) or after (time 1, 2 and $3 \mathrm{~h}$ ) the experimental treatment. Bars represent mean fmol cAMP per oocyte and the standard error of the mean from at least 3 independent experiments. The time zero is significantly different from other groups $(P<0.05)$. 


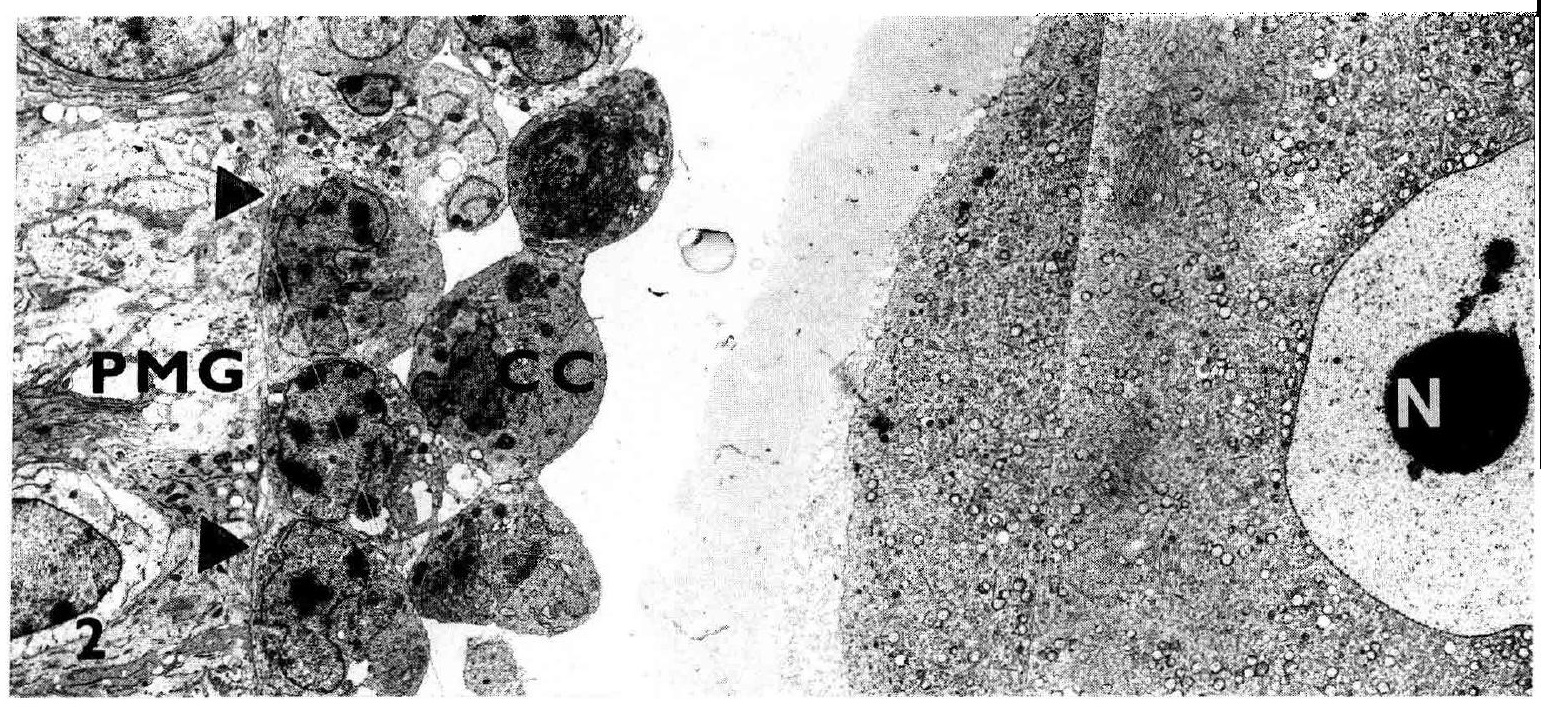

Fig 2. Composition of 3 serial micrographs showing the experimental model used in this study. Large compact nucleolus $(\mathrm{N})$ is visible inside the intact GV of mouse oocyte cultured for $6 \mathrm{~h}$ with pig membrana granulosa (PMG). Mouse cumulus cells $(\mathrm{CC})$ are attached to continuous pig basement membrane (arrowheads) (x 3000$)$.

In addition, round-shaped clumps of chromatin granules $\approx 20 \mathrm{~nm}$ in diameter and numerous nucleolus-like bodies (NLB), were scattered throughout the nucleoplasm. These 3 structures were often associated with the nuclear envelope.

\section{DISCUSSION}

The pig cumulus-enclosed oocytes isolated with attached piece of membrana granulosa did not resume meiosis in vitro (Mot- lik et al, 1991). The isolated pig membrana granulosa (PMG) effectively and reversibly prevented GVBD in heterologous (cattle) oocytes (Kalous et al, 1993). The present data demonstrate that PMG prevented resumption of meiosis in oocytes, also with a rapid GVBD time sequence. Nearly all mouse oocytes retained the GV stage after the 3- and 6-h co-culture. The preincubation of the mouse denuded and cumulusenclosed oocytes for 45 and $60 \mathrm{~min}$, respectively, significantly abolished the inhibitory effect of PMG. The data suggest that the inhibitory activity of PMG, similarly to

Fig 3a,b. Homologous gap junctions remaining in mouse cumulus cells (A) and pig granulosa cells (B) co-cultured for $6 \mathrm{~h}$ (a $\times 90000 ; \mathrm{B} \times 80000)$.

Fig 4. Heterologous contacts (arrowhead) between corona radiata projections and oocyte in mouse OCCs conserved until the end of co-culture $(x 27000)$.

Fig 5. Pig basement membrane separating the mouse (CC) and pig (PMG) compartment of experimental model. The basement membrane is separated into 2 layers in site of gap between the pig and the mouse cells (asterisk) ( $\times 28500$ ). 


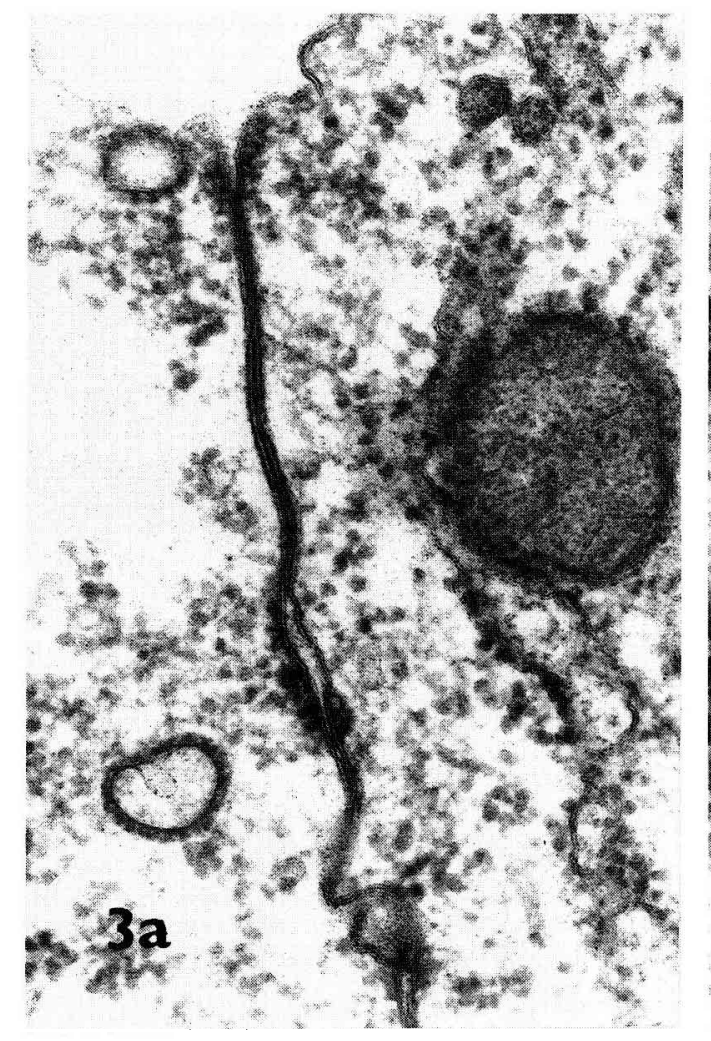

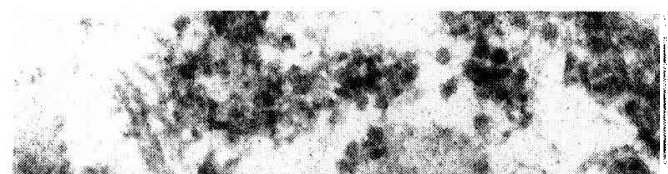

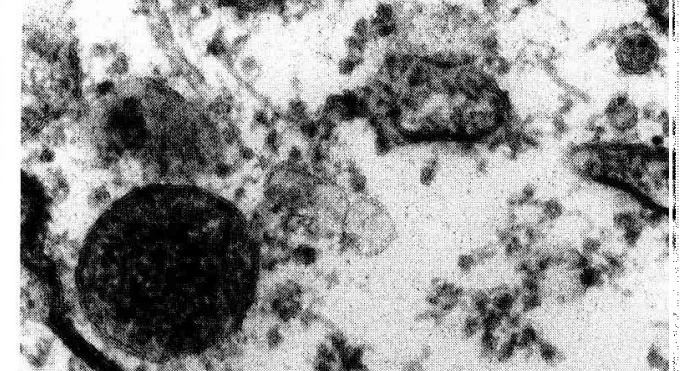

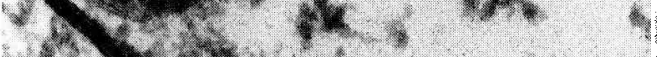

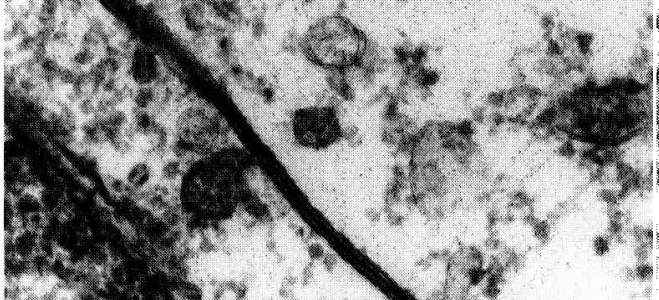

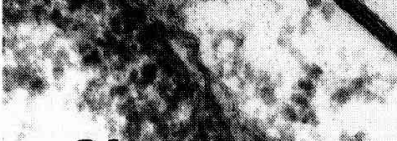

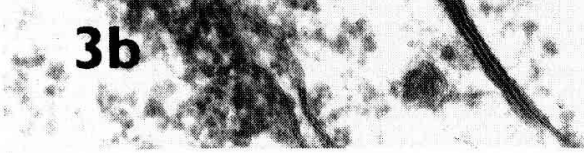

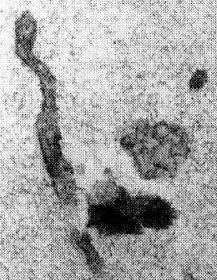

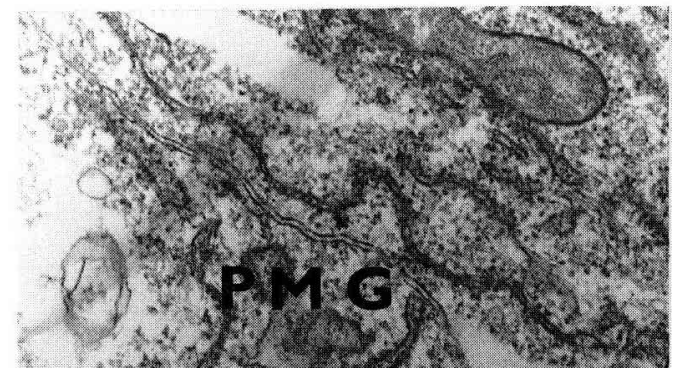

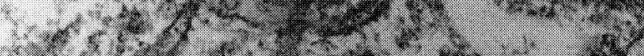
(5.5.5.5.

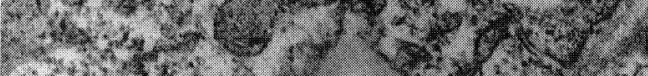

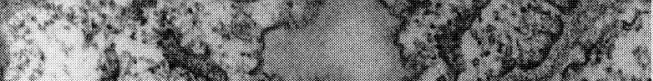

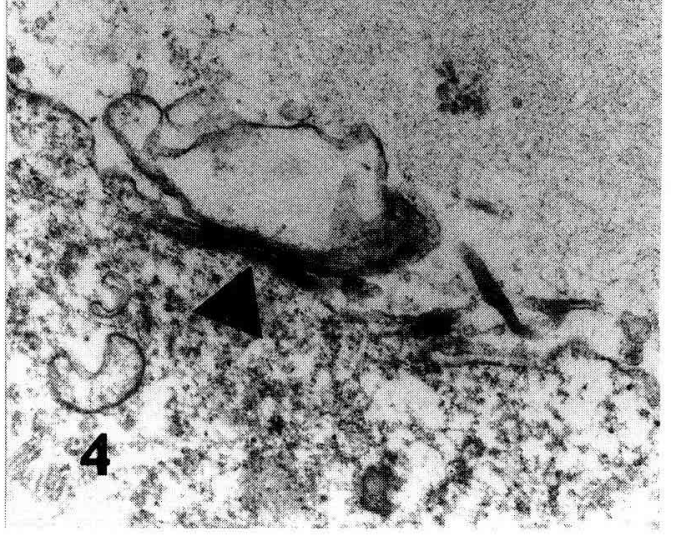

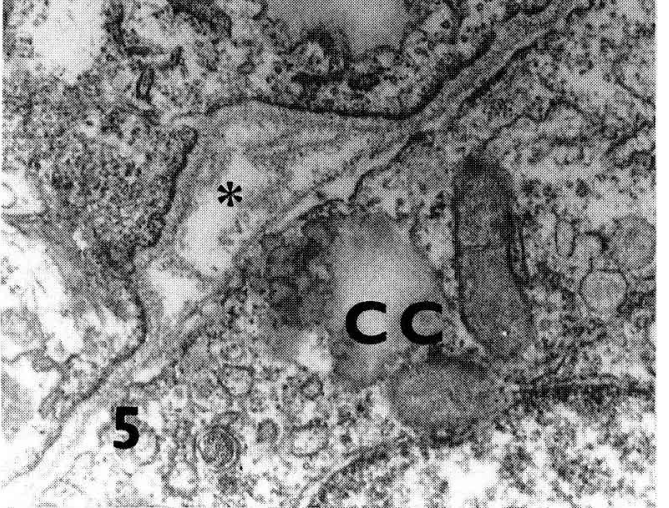




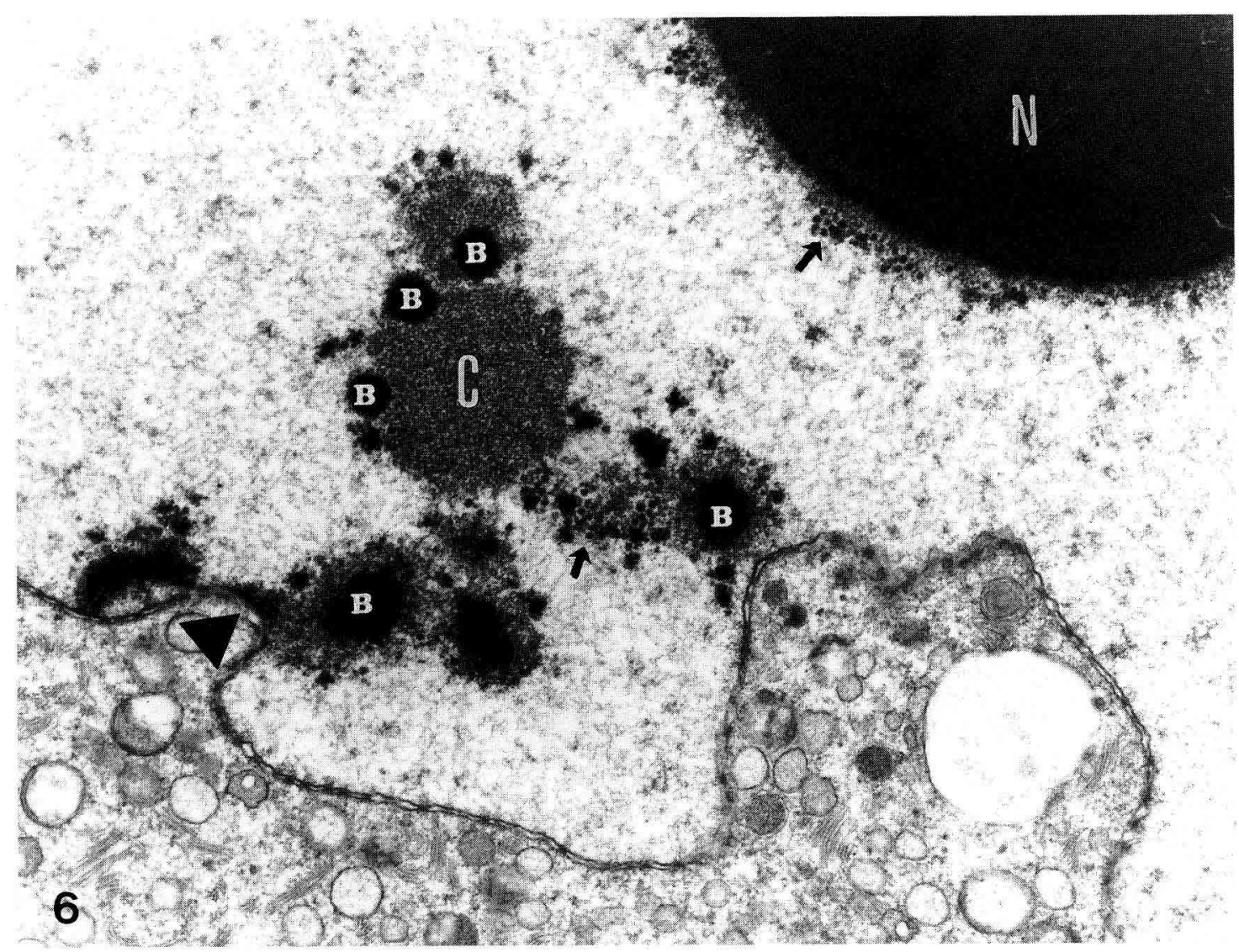

Fig 6. Nuclear ultrastructure of mouse oocyte co-cultured with pig membrana granulosa cells. Large compact nucleolus $(\mathrm{N})$ and small nucleolus-like bodies $(\mathrm{B})$ are surrounded by the rim of chromatin, containing clumps of $80-\mathrm{nm}$ granules (arrows). Note the round-shaped clump of chromatin (C) and the association of nucleolus-like bodies with nuclear membrane (arrowhead) (x 17 500).

the effect of IBMX (Eppig et al, 1983), cannot be exerted after irreversible commitment of mouse oocytes to GVBD.

FSH and cholera toxin significantly increase the cumulus-cell cAMP levels. In spite of the fact that it does not result in any detectable rise in oocyte cAMP, resumption of meiosis in mouse oocytes is postponed (Schultz et al, 1983b). If cAMP is not transmitted from cumulus cells to oo- cytes then some factor other than cAMP may be transferred from cumulus cells to the oocyte to inhibit oocyte maturation. The action of FSH in delaying maturation is mediated by the cumulus cells and it is only transient while all oocytes passed GVBD within $4 \mathrm{~h}$ (Eppig et al, 1983).

The action of $\mathrm{FSH}$, cholera toxin and suboptimal concentrations of dbcAMP in inhibiting mouse oocyte GVBD depends on 
an intact coupling pathway between the cumulus cells and oocytes (Eppig et al, 1983; Schultz et al, 1983b). In the present experiments, the pig granulosa cells as well as the mouse cumulus cells and corona radiata cells with the oolemma were tightly coupled by numerous gap junctions. However, both compartments were strictly separated by the basement membrane. This means that a putative maturation inhibiting factor was secreted by the PMG through the basement membrane and was transported in both cumulus-enclosed and denuded oocytes.

The main characteristic of the commitment period in the mouse oocytes is a decrease in oocyte cAMP levels (Schultz et al, 1983a; Vivarelli et al, 1983; present results). Surprisingly, our experiments also documented this drop in oocytes blocked at the GV stage by PMG. These data could help to answer a question raised by Thibault et al (1987): "Is the decrease in the cAMP level a prerequisite to meiosis resumption?" If cAMP dropped similarly in the ooplasm of committed and inhibited oocytes, this significant decrease could be caused by liberation of oocytes from follicular environment to the culture conditions and a putative intrafollicular inhibitor of meiosis could act downstream of the step which is sensitive to the cAMP level.

\section{ACKNOWLEDGMENTS}

The authors are grateful to E Markalous for his help with the statistical analyses and $L \mathrm{Vy}$ sohlídová and $V$ Pech for skillful technical assistance. This study was supported by the US AID grant No $12.061 \mathrm{E}$.

\section{REFERENCES}

Aberdam E, Hanski E, Dekel N (1987) Maintenance of meiotic arrest in isolated rat oocytes by the invasive adenylate cyclase of Bordetella pertussis. Biol Reprod 36, 530-535

Cho WK, Stern S, Biggers JD (1974) Inhibitory effect of dibutyryl cAMP on mouse oocyte maturation in vivo. J Exp Zoo/ 187, 383-386

Dekel N, Beers WH (1978) Rat oocyte maturation in vitro: relief of CAMP inhibition by gonadotropins. Proc Natl Acad Sci USA 75, 43644373

Eppig JJ, Freter RR, Ward-Bailey PF, Schultz RM (1983) Inhibition of oocyte maturation in the mouse: participation of CAMP, steroid hormones and a putative maturationinhibitory factor. Dev Biol 100, 39-49

Foote WD, Thibault C (1969) Recherches expérimentales sur la maturation in vitro des ovocytes de truie et de veau. Ann Biol Anim Bioch Biophys 9, 329-349

Kalous J, Sutovský P, Rimkevicova Z, Shioya $Y$, Lie LB, Motlík J (1993) Pig membrana granulosa cells prevent resumption of meiosis in cattle oocytes. Mol Reprod Dev 34, 58-64

Liebfried L, First NL (1980) Follicular control of meiosis in the porcine oocyte. Biol Reprod 23, 705-709

Magnusson CJ, Hillensjo T (1977) Inhibition of maturation and metabolism of rat oocytes by cyclic AMP. J Exp Zool 201, 138-147

Mattioli M, Galeati G, Seren E (1988) Effects of follicle somatic cells during pig oocytes maturation on egg penetrability and male pronucleus formation. Gamete Res 20, 177-183

Motlik J, Nagai T, Kikuchi K (1991) Resumption of meiosis in pig oocytes cultured with cumulus and parietal granulosa cells: the effect of protein synthesis inhibition. $J$ Exp Zool 259, 386-391

Pavlok A, Torner H, Motlik J, Fulka J, Kauffold P. Duschinski U (1988) Fertilization of bovine oocytes in vitro: effect of different sources of gametes on fertilization rate and frequency of fertilization anomalies. Anim Reprod Sci 16, 207-213

Pincus G, Enzmann EV (1935) The comparative behaviour of mammalian eggs in vivo and in vitro. I. The activation of ovarian eggs. J Exp Med 62, 665-675

Prochazka R, Nagyova E, Rimkevicova Z, Nagai T, Kikuchi K, Motlík J (1991) Lack of effect of oocytectomy of the porcine cumulus. $J R e-$ prod Fertil 93, 569-576 
Racowsky C (1984) Effect of forskolin on the spontaneous maturation and cycli CAMP content of rat oocyte-cumulus complexes. $J$ Reprod Fertil 72, 107-116

Racowsky C, Baldwin KV (1989) In vitro and in vivo studies reveal that hamster oocyte meiotic arrest is maintained only transiently by follicular fluid, but persistently by membrana/cumulus granulosa cell contact. Dev Biol 134, 297-306

Schultz RM, Montgomery RR, Belanoff J (1983a) Regulation of mouse oocyte maturation. Implication of a decrease in oocyte CAMP and protein dephosphorylation in commitment to resume meiosis. Dev Biol 97 , 264-273

Schultz RM, Montgomery RR, Ward-Bailey PF, Eppig JJ (1983b) Regulation of oocyte maturation in the mouse: possible roles of inter- cellular communication, CAMP, and testosterone. Dev Biol 95, 294-304

Tsafriri A, Channing CP (1975) An inhibitory influence of granulosa cells and follicular fluid upon porcine meiosis in vitro. Endocrinology 96, 922-927

Thibault C, Szöllösi D, Gérard M (1987) Mammalian oocyte maturation. Reprod Nutr Dev 27, 865-896

Vivarelli $E$, Conti $M$, De Felici M, Siracusa $G$ (1983) Meiotic resumption and intracellular cAMP levels in mouse oocytes treated with compounds which act on cAMP metabolism. Cell Differ 12, 271-276

Wasserman PM, Josefowicz WJ, Letourneau GE (1976) Meiotic maturation of mouse oocytes in vitro: inhibition of maturation at specific stages of nuclear progression. $J \mathrm{Cell} \mathrm{Sci}$ 22, 531-535 